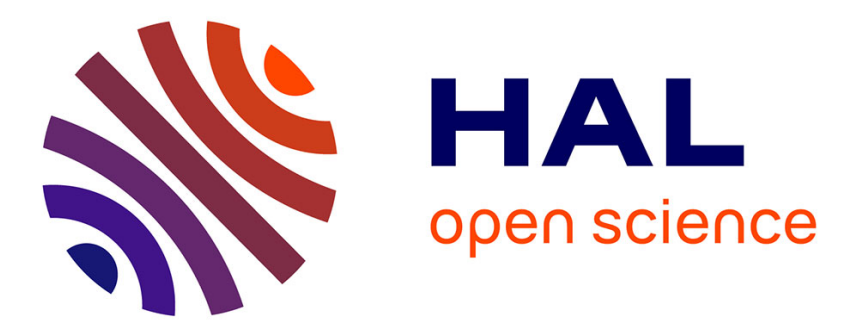

\title{
Adipocyte fatty acid-binding protein as a novel prognostic factor in obese breast cancer patients
}

K. Hancke, D. Grubeck, N. Hauser, R. Kreienberg, J. M. Weiss

\section{To cite this version:}

K. Hancke, D. Grubeck, N. Hauser, R. Kreienberg, J. M. Weiss. Adipocyte fatty acid-binding protein as a novel prognostic factor in obese breast cancer patients. Breast Cancer Research and Treatment, 2009, 119 (2), pp.367-377. 10.1007/s10549-009-0577-9 . hal-00535403

\section{HAL Id: hal-00535403 \\ https://hal.science/hal-00535403}

Submitted on 11 Nov 2010

HAL is a multi-disciplinary open access archive for the deposit and dissemination of scientific research documents, whether they are published or not. The documents may come from teaching and research institutions in France or abroad, or from public or private research centers.
L'archive ouverte pluridisciplinaire HAL, est destinée au dépôt et à la diffusion de documents scientifiques de niveau recherche, publiés ou non, émanant des établissements d'enseignement et de recherche français ou étrangers, des laboratoires publics ou privés. 


\title{
Adipocyte fatty acid-binding protein as a novel prognostic factor in obese breast cancer patients
}

\author{
K. Hancke $\cdot$ D. Grubeck $\cdot$ N. Hauser $\cdot$ \\ R. Kreienberg $\cdot$ J. M. Weiss
}

Received: 30 July 2009/ Accepted: 3 October 2009/Published online: 16 October 2009

(C) Springer Science+Business Media, LLC. 2009

\begin{abstract}
Several adipocytokines, such as leptin or adiponectin, are associated with obesity and the risk for breast cancer. Adiopcyte fatty acid binding-protein (A-FABP) is another protein found in adipose tissue; therefore, we investigated the association of A-FABP with the occurrence and prognosis of breast cancer. In our study, 200 women attending the University of Ulm for breast surgery between the years 2005 and 2007 were included; 159 had histologically confirmed breast cancer; 41 had histologically confirmed benign lesions. Serum levels of A-FABP, leptin, and adiponectin were measured, and their relationship to body-mass-index (BMI), breast cancer, and tumor characteristics were analyzed; logistic regression model was adjusted to age, BMI, menopausal status, use of Hormone Replacement Therapy (HRT), and family history of breast cancer. Serum A-FABP levels were found to be significantly higher in obese (BMI $\geq 25)$ than in non-obese women $(\mathrm{BMI} \leq 24.9), \quad 41.16 \mathrm{ng} / \mathrm{ml}$ and $24.95 \mathrm{ng} / \mathrm{ml}$, respectively $(P<0.0001)$. Independent of obesity, the serum A-FABP levels were significantly higher in breast cancer patients $(34.65 \mathrm{ng} / \mathrm{ml})$ than in healthy controls $(24.47 \mathrm{ng} / \mathrm{ml}), P<0.0001$; the odds ratio $(1.038, P<0.05$, 95\% confidence interval 1.001-1.72) showed a significant association of A-FABP with breast cancer risk. Serum leptin levels showed a strong correlation with BMI $\left(r_{\mathrm{s}}=0.78\right)$ and were significantly higher in breast cancer patients $(20.87 \mathrm{ng} / \mathrm{ml})$ than in controls $(14.90 \mathrm{ng} / \mathrm{ml})$,
\end{abstract}

K. Hancke $(\bowtie) \cdot$ D. Grubeck · R. Kreienberg · J. M. Weiss Department of Obstetrics and Gynaecology, University of Ulm, Prittwitzstr. 43, 89075 Ulm, Germany

e-mail: ka_hancke@yahoo.de

N. Hauser

Hospital of Gynaecology and Obstetrics, Kantonsspital Baden, Switzerland
$P<0.05$. In contrast, adiponectin showed no significant association with breast cancer. Concerning tumor characteristics, A-FABP was positively connected with tumor size $(T \geq 2 \mathrm{~cm}, P<0.05)$ and nodal-status $(P<0.05)$. Our study reveals that high A-FABP serum levels are associated with obesity, breast cancer risk, and adverse tumor characteristics.

Keywords Obesity - Breast cancer .

Adipocyte-fatty acid-binding protein - A-FABP .

Adipocytokines · Leptin

\section{Introduction}

Breast cancer is the most common neoplasm in women and the leading cause of cancer-related deaths worldwide [1, 2]. Obesity is a known independent risk factor for breast cancer development and recent studies state an association with late-stage disease and poor prognosis [3]. Obese women are generally believed to be at increased risk for postmenopausal, rather than premenopausal breast cancer $[4,5]$. The possible reasons for the higher risk of breast cancer in obese women are the elevated estrogen levels insulin resistance with consecutive hyperinsulinemia, and the influence of insulin-like-growth-factor (IGF) in the pathogenesis of breast cancer [6, 7]. Recently, several studies indicated that the adipose tissue itself is an endocrine organ which could influence tumor growth or differentiation by adipose tissue-derived hormones [2] called adipocytokines, e.g., leptin, resistin, or adiponectin $(\mathrm{ApN})$. Leptin is elevated proportionally with increasing bodymass-index (BMI) [2, 3, 8], and the adipocytes of white adipose tissue predominantly produce and secrete it [2]. Leptin, belonging to the cytokine family, has a biological 
effect on breast cancer development and progression. This effect is marked by the breast cancer cells proliferating, the proteolytic enzyme expression increasing during the metastatic process, angiogenesis being stimulated, and aromatase activity being enhanced [2, 3, 9]. Breast cancer patients with an over-expression of leptin show lower survival rate $[3,10]$. Besides leptin, another well-known adipocytokine is ApN, produced exclusively by the adipose tissue, appearing to be inversely related to leptin; ApN serum levels are inversely correlated with BMI [3], and the studies confirm a significant inverse correlation between the serum adiponectin levels and poor prognosis of breast cancer [11, 12].

Although many studies demonstrate the relationship of adipocytokines and its derivates with the risk of breast cancer in obese women, there are still several unexplained factors, and therefore, the quest for other associated factors is emerging. Besides leptin and $\mathrm{ApN}$, fatty acid-binding proteins (FABPs) are a family of proteins expressed in a tissue-specific manner, and involved in transporting fatty acids to cellular compartments, modulating intracellular lipid metabolism, and regulating gene expression [13, 14]. Adipocyte-FABP (A-FABP) is predominantly expressed in the cytosol of mature adipocytes and has been recently described as associated with obesity markers and obesityrelated diseases [13]. A-FABP is recognized to affect insulin sensitivity, lipid metabolism, and an inflammatory response associated with atherosclerosis [13], and circulating A-FABP could be involved in the pathogenesis of breast cancer $[15,16]$. Therefore, in our study, we measured the serum levels of leptin, ApN, and A-FABP in breast cancer patients and healthy controls. We determined whether the serum levels of A-FABP are linked to obesity, breast cancer, and tumor characteristics.

\section{Materials and methods}

\section{Subjects}

During the period between March 2005 and February 2007, 247 consecutive patients with findings suspicious for breast cancer on mammography were seen in the outpatient consultation at the Obstetrics and Gynecology department of the University of Ulm, and after informed consent and age $>18$ included. Exclusion criteria were histologically DCIS (ductal carcinoma in situ), LCIS (lobular carcinoma in situ), and a past history of breast cancer at the same or the other site. Forty-seven of the selected women were excluded because of exclusion criteria mentioned above, and therefore, the remaining 200 women were included in this study. All of them had mammary gland surgery, 159 women had histologically confirmed breast cancer (considered as cases), and 41 women had histologically confirmed benign lesions (considered as controls). Demographic data are shown in Table 1.

Blood samples were taken during the first visit to our hospital, centrifuged, and stored at $-80^{\circ} \mathrm{C}$ until assay. The Body-mass-index (BMI) was calculated as body weight $(\mathrm{kg})$ divided by body height squared $\left(\mathrm{m}^{2}\right)$. All the cases and controls were interviewed on demographic, reproductive variables, and past medical and family history. Postmenopausal status was defined as the absence of menorrhea within the past 1 year. In total, 65 women were found to be

Table 1 Demographic data and baseline characteristics of all patients stratified by disease and menopausal status

\begin{tabular}{|c|c|c|c|c|c|c|c|c|c|}
\hline & \multirow[b]{2}{*}{$\begin{array}{l}\text { Cases } \\
n=159\end{array}$} & \multirow[b]{2}{*}{$\begin{array}{l}\text { All Controls } \\
n=41\end{array}$} & \multirow[b]{2}{*}{$P$} & \multicolumn{3}{|c|}{ Premenopausal } & \multicolumn{3}{|c|}{ Postmenopausal } \\
\hline & & & & $\begin{array}{l}\text { Cases } \\
n=40\end{array}$ & $\begin{array}{l}\text { Controls } \\
n=25\end{array}$ & $P$ & $\begin{array}{l}\text { Cases } \\
n=119\end{array}$ & $\begin{array}{l}\text { Controls } \\
n=16\end{array}$ & $P$ \\
\hline Age mean $( \pm$ SEM $)$ & $59.51(1.0)$ & $49(1.7)$ & $<0.0001$ & $42.95(0.8)$ & $43.04(1.1)$ & 0.8026 & $65.08(0.8)$ & $60.25(1.9)$ & 0.051 \\
\hline BMI mean $( \pm$ SEM $)$ & $25.83(0.4)$ & $24.25(0.6)$ & 0.052 & $24.23(0.6)$ & $24.04(0.8)$ & 0.9570 & $26.37(0.4)$ & $24.58(0.9)$ & 0.1702 \\
\hline History of hyperlipidemia (n/\%) & $23(14.5 \%)$ & $3(7.3 \%)$ & 0.2286 & 0 & 0 & - & $23(19.3 \%)$ & $3(18.5 \%)$ & 0.961 \\
\hline History of HRT (n/\%) & $16(10.1 \%)$ & $3(7.3 \%)$ & 0.597 & 0 & 0 & - & $16(13.5 \%)$ & $3(18.5 \%)$ & 0.574 \\
\hline History of Diabetes mellitus ( $\mathrm{n} / \%$ ) & $19(11.9 \%)$ & $1(2.4 \%)$ & 0.072 & $2(5 \%)$ & 0 & - & $17(14.3 \%)$ & $1(6.3 \%)$ & 0.3812 \\
\hline $\begin{array}{l}\text { Family history of breast } \\
\text { cancer }(\mathrm{n} / \%)\end{array}$ & $39(24.5 \%)$ & $7(17.1 \%)$ & 0.252 & $9(22.5 \%)$ & $5(20 \%)$ & 0.509 & $30(25.2 \%)$ & $2(12.5 \%)$ & 0.271 \\
\hline $\begin{array}{l}\text { Family history of other } \\
\text { cancer }(\mathrm{n} / \%)\end{array}$ & $50(31.4 \%)$ & $25(60.9 \%)$ & 0.416 & $16(40 \%)$ & $7(28 \%)$ & 0.262 & $34(28.6 \%)$ & $9(56.3 \%)$ & $<0.05$ \\
\hline $\begin{array}{l}\text { Mean age of menarche } \\
\text { mean }( \pm \text { SEM })\end{array}$ & $13.3(0.1)$ & $13.5(0.3)$ & 0.866 & $12.4(0.2)$ & $13.4(0.4)$ & 0.345 & $13.7(0.1)$ & $13.7(0.4)$ & 0.818 \\
\hline $\begin{array}{l}\text { Mean number of children } \\
\text { mean }( \pm \text { SEM })\end{array}$ & $2.2(0.1)$ & $1.8(0.3)$ & 0.180 & $1.8(0.1)$ & $1.6(0.3)$ & 0.4754 & $2.4(0.1)$ & $2(0.3)$ & 0.462 \\
\hline $\begin{array}{l}\text { Mean age of menopause } \\
\text { mean }( \pm \text { SEM })\end{array}$ & $48.65(0.5)$ & $47.3(0.9)$ & 0.556 & - & - & - & $48.65(0.5)$ & $47.3(0.9)$ & 0.556 \\
\hline
\end{tabular}


premenopausal (40 cases, 25 controls), and 135 postmenopausal (119 cases, 16 controls). Study protocol was approved by the University of Ulm Medical School Ethics Committee, and written informed consent was obtained from all the participants.

Among the cases, classification of malignant tumors (TNM = tumor size, nodal-status, and metastasis), grading $(\mathrm{G})$, and hormone receptor status (estrogen [ER] and progesterone receptor $[\mathrm{PR}]$ ) were confirmed by the pathologists. Prognosis was considered good if the following criteria were met: tumor size $\leq 2 \mathrm{~cm}(\leq \mathrm{T} 1)$, grading $\mathrm{G} 1$ or lymph nodes without metastasis (N0); however, prognosis was considered worse if tumor size was $\geq \mathrm{T} 2$, grading $\geq \mathrm{G} 2$ or N1.

The main aim of our study was to demonstrate an association of the adipocytokines with breast cancer. Second, serum levels of A-FABP, leptin, and ApN were tested to see if they were related to obesity. Third, the hypothesis that the serum levels of these adipocytokines were linked to tumor characteristics was also tested. Sample size calculation was done to investigate our main aim: with an expected 4:1 ratio of cases to controls in our breast consultation outpatient clinic, an estimated medium effect size of 0.5 and an alpha error of 0.05 , the estimated sample size was 200 (160 cases and 40 controls). We collected $\sim 20 \%$ more participants as certain exclusion criteria could be verified only post surgery. After excluding 47 non-eligible patients, we were left with $n=200$ patients, 159 cases, and 41 controls. In order to analyze whether obesity is associated with adipocytokines, non-obese $(\mathrm{BMI} \leq 24.9)$ women $(n=106)$ were compared to obese (BMI $\geq 25)$ women $(n=94)$. A post hoc sample size calculation of this group showed a rather high effect size of 1.2. In order to identify any relationship between adipocytokines and TNM, the 159 cases were analyzed. After stratification for menopausal status, the sample sizes decreased; thus, the effect sizes and power of the analyses were not very high anymore.

\section{Assays}

Commercially available Sandwich Enzyme-linked Immunosorbent Assays (Sandwich ELISAs) were used to determine serum levels of total leptin, ApN, and A-FABP (Biovendor-Laboratory Medicine, Heidelberg, Germany), and measurements were conducted consistent with the manufacturer's instructions. The intra- and inter-assay coefficients of variation were 5.7 and $6.5 \%$ for leptin, 5.5 and $8.5 \%$ for $\mathrm{ApN}$, and 5.3 and $3.9 \%$ for A-FABP, respectively. The blood samples were labeled only by number and ordered randomly; thus, medical and technical assistants were blinded with respect to the samples.
Statistical analysis

Data were analyzed using Excel, SAS 9.1, and Prism 5.2. Mean and standard error of the mean (SEM) were calculated among cases and controls, and subjects were stratified into subgroups according to the menopausal status. Comparison among the groups was performed using the MannWhitney- $U$-test. Correlation was calculated with the Spearman correlation coefficient. Logistic regression analysis with backward elimination was performed to evaluate the impact of A-FABP, leptin, and ApN on breast cancer risk, adjusted to age, BMI, menopausal status, use of hormone replacement therapy (HRT), and family history of breast cancer. A $P$ value less than 0.05 was considered statistically significant.

\section{Results}

Baseline characteristics of our cohort

Table 1 shows the distribution of our cohort of 159 and 41 controls by demographic data, baseline characteristics, and stratified by menopausal status.

Total cohort

The mean age of our cohort was 57.51 years and mean BMI was 25.51 (SD 4.38, SEM 0.31) with a correlation of $r_{\mathrm{s}}=0.32$ of BMI and age. In addition, the mean BMI of the controls was lower than that of the cases, 24.25 (SEM 0.57 ) and 25.83 (SEM 0.36), respectively, $P=0.052$. Therefore, in our cohort, obesity increased with age, and the risk of breast cancer increased with obesity.

Stratified by menopausal status

Postmenopausal cases were older than the controls, 65.08 and 60.25 years, respectively, $(P=0.051)$, but no such age difference was observed in premenopausal cases. Further, postmenopausal cases had a higher BMI than postmenopausal controls, 26.37 (SEM 0.4) and 24.58 (SEM 0.9), respectively $(P=0.170)$, though no association of BMI and breast cancer in premenopausal patients was observed. Our results showed the tendency for a higher BMI in postmenopausal cases than in postmenopausal controls, but the interpretation needs to be cautiously accepted because of non-significant results.

Mean serum levels of adipocytokines stratified by breast cancer

Table 2 shows the mean, SEM, and $P$ value of the adipocytokines measured for cases and that of the controls of the 
Table 2 Comparison of adipocytokines serum concentrations between cases and controls stratified by menopausal status

\begin{tabular}{|c|c|c|c|c|c|c|c|c|c|}
\hline & \multicolumn{3}{|c|}{$\begin{array}{l}\text { All }(n=200, \text { cases } n=159 \\
\text { controls } n=41)\end{array}$} & \multicolumn{3}{|c|}{$\begin{array}{l}\text { Prem. }^{\text {b }}(n=65, \text { cases } n=40, \\
\text { controls } n=25)\end{array}$} & \multicolumn{3}{|c|}{$\begin{array}{l}\text { Postm. }^{\mathrm{b}}(n=135, \text { cases } n=119 \\
\text { controls } n=16)\end{array}$} \\
\hline & Mean & SEM & $P$ & Mean & SEM & $P$ & Mean & SEM & $P$ \\
\hline \multicolumn{10}{|l|}{ A-FABP ${ }^{\mathrm{a}}$} \\
\hline Controls & 24.47 & 2.2 & $<0.0001$ & 20.65 & 2.1 & 0.058 & 30.44 & 4.1 & $<0.05$ \\
\hline Cases & 34.65 & 1.0 & & 24.36 & 1.54 & & 38.11 & 1.4 & \\
\hline \multicolumn{10}{|l|}{ Leptin $^{\mathrm{a}}$} \\
\hline Controls & 14.90 & 2.0 & $<0.05$ & 14.83 & 2.9 & 0.522 & 15.06 & 2.5 & 0.078 \\
\hline Cases & 20.87 & 1.2 & & 15.26 & 1.8 & & 22.76 & 1.5 & \\
\hline \multicolumn{10}{|l|}{$\mathrm{ApN}^{\mathrm{a}}$} \\
\hline Controls & 17.77 & 1.0 & 0.662 & 17.14 & 1.2 & 0.399 & 18.77 & 1.7 & 0.804 \\
\hline Cases & 18.53 & 0.6 & & 15.78 & 0.95 & & 19.45 & 0.7 & \\
\hline \multicolumn{10}{|l|}{ L/A-Ratio ${ }^{c}$} \\
\hline Controls & 1.02 & 0.18 & $<0.05$ & 1.08 & 0.26 & 0.296 & 0.92 & 0.11 & 0.119 \\
\hline Cases & 1.33 & 0.09 & & 1.18 & 0.17 & & 1.38 & 0.19 & \\
\hline
\end{tabular}

${ }^{a}$ A-FABP ng/ml, leptin $\mathrm{ng} / \mathrm{ml}$, adiponectin $(\mathrm{ApN}) \mu \mathrm{g} / \mathrm{ml}$

${ }^{\mathrm{b}}$ prem. $=$ premenopausal, postm. $=$ postmenopausal

${ }^{c}$ L/A-Ratio: leptin-to-adiponectin-Ratio

total cohort, stratified by menopausal status. The leptin-toadiponectin-ratio (L/A-ratio) is presented in Table 2. Table 3 shows logistic regression models to evaluate the risk of breast cancer.

Total cohort

Analyses of our cohort show significantly higher serum levels of A-FABP in cases than in controls, 34.65 and $24.47 \mathrm{ng} / \mathrm{ml}$, respectively $(P<0.0001)$. Leptin serum levels were also significantly higher in cases than in controls, 20.87 and $14.90 \mathrm{ng} / \mathrm{ml}(P<0.05)$, respectively. However, no significant difference was evident between the cases $(18.53 \mu \mathrm{g} / \mathrm{ml})$ and controls $(17.77 \mu \mathrm{g} / \mathrm{ml})$ considering the ApN serum levels. However, the L/A-ratio is higher in the cases than in the controls, 1.33 and 1.02, respectively $(P<0.05)$. Our analyses reveal that the cases

Table 3 Logistic regression model ${ }^{\mathrm{a}}$ to evaluate the risk of breast cancer

\begin{tabular}{llll}
\hline & $\mathrm{OR}^{\mathrm{b}}$ & $95 \% \mathrm{CI}^{\mathrm{c}}$ & $P$ Value \\
\hline A-FABP & 1.036 & $1.001-1.072$ & 0.044 \\
Leptin & 1.021 & $0.992-1.051$ & 0.163 \\
Adiponectin & 1.005 & $0.945-1.069$ & 0.883 \\
Menopausal status (Age) & 3.378 & $1.478-7.721$ & 0.004
\end{tabular}

\footnotetext{
${ }^{a}$ adjusted to age, BMI, menopausal status, HRT and family history of breast cancer

b $O R$ odds ratio

c $C I$ confidence interval
}

have significantly higher serum levels of A-FABP and leptin than the controls.

Stratified by menopausal status

Mean serum A-FABP levels appeared significantly higher in postmenopausal cases than in postmenopausal controls, 38.11 and $30.44 \mathrm{ng} / \mathrm{ml}$, respectively $(P<0.05)$. The serum levels of leptin were higher in postmenopausal cases than in postmenopausal controls, but without statistical significance $(P=0.078)$. No significant difference was seen in the postmenopausal serum levels of ApN $(P=0.804)$. However, the L/A-ratio was higher in the cases than in the controls, as well as in premenopausal, 1.18 versus 1.08, respectively $(P=0.296)$ as in postmenopausal 1.38 and 0.92 , respectively $(P=0.119)$. Concerning premenopausal patients, there was no significant difference in any of the adipocytokines. These data show that after stratifying by menopausal status, postmenopausal, not premenopausal, cases have significantly higher serum A-FABP levels.

Logistic regression models

Logistic regression models were performed to evaluate the impact of adipocytokines on breast cancer risk. The models were adjusted to age, BMI, menopausal status, use of HRT, and family history of breast cancer. The estimated odds ratios are shown in Table 3 with $95 \%$ confidence interval (CI) and $P$ values. The analyses show that the risk for breast cancer is significantly increased in postmenopausal women with an OR of $3.378(P<0.005)$ compared with 
premenopausal women. An increment in the serum A-FABP levels of $1 \mathrm{ng} / \mathrm{ml}$ leads to a significant higher risk for breast cancer, $\mathrm{OR}=1.036(P<0.05)$. Elevation of serum leptin levels or decreasing of the serum ApN levels did not significantly change the risk of breast cancer.

Analyses and correlation of mean adipocytokine serum levels and BMI (Table 4)

\section{Total cohort}

Mean serum A-FABP levels were significantly higher in obese than in non-obese women, 41.16 and $24.95 \mathrm{ng} / \mathrm{ml}$, respectively $(P<0.0001)$; the Spearman correlation of A-FABP and BMI was $r_{\mathrm{s}}=0.551$. Mean serum leptin levels were also significantly higher in obese than in nonobese women, $29.21 \mathrm{ng} / \mathrm{ml}$ and $11.18 \mathrm{ng} / \mathrm{ml}$, respectively $(P<0.0001)$, with a strong correlation of leptin and BMI $\left(r_{\mathrm{s}}=0.747\right)$. In contrast, mean serum levels of ApN were significantly lower in obese than in non-obese, 17.26 and $19.36 \mu \mathrm{g} / \mathrm{ml}$, respectively $(P<0.05)$. This is in concert with other published data revealing a significant positive correlation of A-FABP and leptin with BMI and an inverse correlation of ApN and BMI.

\section{Stratified by menopausal status}

In both the premenopausal and the postmenopausal women, the serum A-FABP and leptin levels were significantly higher in obese than in the non-obese $(P<0.0001)$ women. Spearman correlation of A-FABP and BMI was $r_{\mathrm{s}}=0.644$ and $r_{\mathrm{s}}=0.531$ in pre- and postmenopausal women, respectively. Correlation of leptin and BMI was strong in pre- and postmenopausal women, $r_{\mathrm{s}}=0.705$ and $r_{\mathrm{s}}=0.764$, respectively. Serum ApN levels were again lower in obese pre- and postmenopausal women than in the non-obese, but the inverse correlation was not strong $\left(r_{\mathrm{s}}=-0.414\right.$ and -0.153 in pre- and postmenopausal, respectively). Our data demonstrate that correlation of A-FABP and leptin with BMI is independent of menopausal status.

Analyses of the mean serum levels of adipocytokines and BMI, stratified by disease

As our results show that A-FABP and serum leptin levels increase with obesity in all women, and that further serum levels are higher in the cases than in the controls, our curiosity was roused as to whether the same results persisted within the subgroups. Table 5 shows the analyses of serum levels of each adipocytokine depending on BMI and presence of breast cancer. First, the serum levels of each adipocytokine of the obese controls were compared to the non-obese controls; similarly, the obese cases were compared to non-obese cases. Second, the serum levels of the obese controls were compared to that of the obese cases, and the non-obese controls to the non-obese cases. Statistical significance was proved for serum levels within the BMI dependent on the presence of breast cancer and on the contrary, within breast cancer cases (and controls) dependent on the BMI.

\section{Total cohort}

Mean serum A-FABP levels were significantly higher in the obese controls than in the non-obese controls $(P<0.005)$, and significantly higher in the obese cases than in the non-obese cases $(P<0.0001)$. In addition,

Table 4 Comparison of adipocytokines serum concentrations between obese and non-obese women stratified by menopausal status and Spearman Correlation $\left(r_{\mathrm{s}}\right)$ of adipocytokines and BMI

\begin{tabular}{|c|c|c|c|c|c|c|c|c|c|}
\hline \multirow{3}{*}{ BMI } & \multicolumn{3}{|c|}{$\begin{array}{l}\text { All }(n=200 ; \text { obese } n=94 \\
\text { non-obese } n=106\end{array}$} & \multicolumn{3}{|c|}{$\begin{array}{l}\text { Prem. }{ }^{\text {b }}(n=65 \text {; obese } n=18 \\
\text { non-obese } n=47)\end{array}$} & \multicolumn{3}{|c|}{$\begin{array}{l}\text { Postm. }{ }^{\mathrm{b}} \text { (obese }=76, \text { non-obese } \\
n=59)\end{array}$} \\
\hline & $\leq 24.9$ & $\geq 25.0$ & $r_{\mathrm{s}}^{\mathrm{c}}$ & $\leq 24.9$ & $\geq 25.0$ & $r_{\mathrm{s}}$ & $\leq 24.9$ & $\geq 25.0$ & $r_{\mathrm{s}}$ \\
\hline & Mean \pm SEM & Mean \pm SEM & & Mean \pm SEM & Mean \pm SEM & & Mean \pm SEM & Mean \pm SEM & \\
\hline \multirow[t]{2}{*}{ A-FABP ${ }^{\mathrm{a}}$} & $24.95(1.0)$ & 41.16 (1.6) & 0.551 & $19.26(1.1)$ & $32.54(2.5)$ & 0.644 & $29.48(1.4)$ & $43.2(1.8)$ & 0.531 \\
\hline & $P<0.0001$ & & & $P<0.0001$ & & & $P<0.0001$ & & \\
\hline \multirow[t]{2}{*}{ Leptin $^{a}$} & $11.18(0.7)$ & $29.21(1.6)$ & 0.747 & $10.04(0.9)$ & $28.28(3.8)$ & 0.705 & $12.09(1.1)$ & $29.43(1.8)$ & 0.764 \\
\hline & $P<0.0001$ & & & $P<0.0001$ & & & $P<0.0001$ & & \\
\hline \multirow[t]{2}{*}{$\mathrm{ApN}^{\mathrm{a}}$} & $19.36(0.8)$ & $17.26(0.7)$ & -0.157 & $17.71(0.95)$ & $12.64(0.9)$ & -0.414 & $20.67(1.2)$ & $18.36(0.8)$ & -0.153 \\
\hline & $P<0.05$ & & & $P=0.0006$ & & & $P=0.1513$ & & \\
\hline
\end{tabular}

${ }^{a}$ A-FABP ng/ml, leptin $\mathrm{ng} / \mathrm{ml}$, adiponectin $(\mathrm{ApN}) \mu \mathrm{g} / \mathrm{ml}$

b prem. $=$ premenopausal

postm. $=$ postmenopausal

${ }^{c}$ Spearman correlation $=r_{\mathrm{s}}$ 
Table 5 Comparison of adipocytokines serum concentrations between breast cancer patients and controls stratified by BMI and menopausal status

\begin{tabular}{|c|c|c|c|c|c|c|c|c|c|}
\hline \multirow[b]{2}{*}{ BMI } & \multicolumn{3}{|c|}{ All ( $n=200159$ cases, 41 controls $)$} & \multicolumn{3}{|c|}{ Prem. $^{\mathrm{d}}$ ( $n=6540$ cases, 25 controls) } & \multicolumn{3}{|c|}{ Postm. $^{\mathrm{d}}$ ( $n=135119$ cases, 16 controls) } \\
\hline & $\begin{array}{l}\leq 24.9 \\
\text { Mean } \pm \text { SEM }\end{array}$ & $\begin{array}{l}\geq 25.0 \\
\text { Mean } \pm \text { SEM }\end{array}$ & $\mathrm{pBMI}^{\mathrm{b}}$ & $\begin{array}{l}\leq 24.9 \\
\text { Mean } \pm \text { SEM }\end{array}$ & $\begin{array}{l}\geq 25.0 \\
\text { Mean } \pm \text { SEM }\end{array}$ & $\mathrm{pBMI}^{\mathrm{b}}$ & $\begin{array}{l}\leq 24.9 \\
\text { Mean } \pm \text { SEM }\end{array}$ & $\begin{array}{l}\geq 25.0 \\
\text { Mean } \pm \text { SEM }\end{array}$ & $\mathrm{pBMI}^{\mathrm{b}}$ \\
\hline $\begin{array}{l}\text { Control } \\
\text { pDisease }^{c}\end{array}$ & $\begin{array}{l}18.34(1.0) \\
0.0002\end{array}$ & $\begin{array}{l}34.05(4.4) \\
<0.05\end{array}$ & $<0.005$ & $\begin{array}{l}17.00(1.2) \\
0.1062\end{array}$ & $\begin{array}{l}28.40(5.1) \\
0.1731\end{array}$ & 0.051 & $\begin{array}{l}21.19 \text { (1.6) } \\
<0.05\end{array}$ & $\begin{array}{l}39.69(6.7) \\
0.3475\end{array}$ & $<0.05$ \\
\hline $\begin{array}{l}\text { Cases } \\
\text { Leptin }^{\mathrm{a}}\end{array}$ & $27.18(1.2)$ & $42.22(1.7)$ & $<0.0001$ & $20.84(1.5)$ & $33.63(2.4)$ & 0.0001 & 30.78 (1.6) & 43.61 (1.9) & $<0.0001$ \\
\hline $\begin{array}{l}\text { Control } \\
\text { pDisease }^{c}\end{array}$ & $\begin{array}{l}12.07(1.3) \\
0.0523\end{array}$ & $\begin{array}{l}24.58(1.4) \\
0.1978\end{array}$ & $<0.0001$ & $\begin{array}{l}9.27(1.5) \\
0.4391\end{array}$ & $\begin{array}{l}26.65(7.2) \\
0.6497\end{array}$ & $<0.05$ & $\begin{array}{l}7.62(1.9) \\
0.0694\end{array}$ & $\begin{array}{l}22.49(2,7) \\
0.2901\end{array}$ & $<0.005$ \\
\hline $\begin{array}{l}\text { Cases } \\
\mathrm{AnP}^{\mathrm{a}}\end{array}$ & $12.00(0.9)$ & $29.86(1.8)$ & $<0.0001$ & $10.62(1.2)$ & 27.47 (3.9) & 0.0002 & $12.79(1.2)$ & 30.24 (1.9) & $<0.0001$ \\
\hline $\begin{array}{l}\text { Control } \\
\text { pDisease }^{c}\end{array}$ & $\begin{array}{l}19.72(1.2) \\
0.9251\end{array}$ & $\begin{array}{l}16.31(1.8) \\
0.3273\end{array}$ & 0.0712 & $\begin{array}{l}19.03(1.5) \\
0.3748\end{array}$ & $\begin{array}{l}13.11(1.2) \\
0.6497\end{array}$ & $<0.05$ & $\begin{array}{l}18.03(1.5) \\
0.5875\end{array}$ & $\begin{array}{l}19.50(3.0) \\
0.9662\end{array}$ & 0.9591 \\
\hline Cases & $19.56(0.9)$ & $17.48(0.8)$ & 0.1677 & $16.87(1.1)$ & $12.92(1.5)$ & $<0.05$ & 21.09 (1.3) & $18.22(0.8)$ & 0.1334 \\
\hline
\end{tabular}

${ }^{a}$ A-FABP ng/ml, leptin $\mathrm{ng} / \mathrm{ml}$, adiponectin (ApN) $\mu \mathrm{g} / \mathrm{ml}$

b $p B M I P$ Value of obese versus non-obese

${ }^{c}$ pDisease $P$ Value of breast cancer versus control

${ }^{\mathrm{d}}$ prem. premenopausal, postm. postmenopausal

mean serum A-FABP levels were significantly higher in cases than in controls, independent of BMI, $P=0.0002$ in the non-obese and $P<0.05$ in the obese. These results show that obesity and breast cancer are associated with higher serum A-FABP levels.

Concerning leptin, the serum levels were significantly higher in obese controls than in non-obese controls $(P<0.0001)$ and significantly higher in obese cases than in non-obese cases $(P<0.0001)$. Comparing obese cases and controls, no significant difference was observed, nor was any seen in the non-obese cases and controls. These results show that obesity is associated with high serum leptin levels, but in our cohort, no association of cases and controls is observed within one BMI-group.

Concerning ApN, statistical difference existed in neither direction, nor within BMI, nor within the disease.

\section{Stratified by menopausal status}

Postmenopausal obese controls showed significantly higher mean serum A-FABP levels than non-obese controls $(P<0.05)$, and obese cases had significantly higher mean serum A-FABP levels than non-obese cases $(P<0.0001)$. Non-obese cases had significantly higher serum A-FABP levels than non-obese controls, but higher serum levels in obese cases were not statistically significant compared with obese controls. In premenopausal women, serum A-FABP levels were significantly higher in obese cases than in nonobese cases, but no statistically significant difference was seen in obese controls and non-obese controls, and there was no statistical difference of disease within the BMIgroup. This shows that high serum A-FABP levels are associated with obesity and breast cancer in postmenopausal, but not in premenopausal women.

Leptin serum levels were significantly higher in postmenopausal, but not in premenopausal obese controls than in non-obese controls $(P=0.051$ premenopausal and $P<0.05$ postmenopausal). Mean serum leptin levels were significantly higher in obese cases than in nonobese cases $(P=0.0001$ premenopausal and $P<0.0001$ postmenopausal) independently of menopausal status. There was no significant difference between non-obese cases and controls or obese cases and controls in either menopausal group. These results show that obesity is associated with high leptin levels independent of the menopausal status.

Concerning ApN, serum premenopausal levels in obese controls were significantly lower than those of non-obese controls $(P<0.05)$ and significantly lower in premenopausal obese cases than in non-obese cases. There was no difference in postmenopausal cases or controls, nor was any difference seen within the BMI-group. These results show that obesity is associated with lower serum ApN levels in premenopausal, not in postmenopausal women. 
Analysis of adipocytokines and tumor characteristics

Table 6 and Fig. 1 show serum levels of adipocytokines and tumor characteristics, of which tumor size ( $T$-stage), grading (G1, G2, and G3), and nodal involvement $(\mathrm{N})$ were of major interest. Therefore, detailed analyses of T-, G-, and N-status are listed below, and data of the total cohort are shown stratified by menopausal status.

\section{Adipocytokines and tumor size (T-stage)}

In all the cases, the mean serum A-FABP levels are significantly higher with higher $T$-stage $(P<0.05)$. After stratifying by menopausal status, this association cannot be demonstrated (pre- and postmenopausal patients, $P=0.1535$ and $P=0.1076$, respectively).

Considering leptin, mean serum levels of all cases are higher with $T \geq 2$ than $T=1$ without being statistically significant $(P=0.0897)$. After stratifying by menopausal status, statistical significance was demonstrated only in premenopausal patients $(P<0.05)$, and not in postmenopausal patients $(P=4437)$. These results suggest an association between tumor size and leptin, only in premenopausal cases.

Concerning ApN, no significant difference in the mean serum levels with greater tumor size, neither in total cohort, nor in premenopausal, nor in postmenopausal, was noted.

\section{Adipocytokines and Grading $(G)$}

Mean serum A-FABP levels appear to be higher with higher grading, but there is no significant difference in grading, either of A-FABP, or leptin or $\mathrm{ApN}$ with and without stratifying by menopausal status. Therefore, the serum levels of the examined adipocytokines do not relate to grading.

\section{Adipocytokines and nodal-status (N-status)}

Concerning nodal-status, N0 versus N1, mean serum levels of A-FABP were significantly higher with positive lymph nodes in the total cohort $(P<0.05)$ and premenopausal patients $(P<0.01)$, non-significantly higher in postmenopausal patients $(P=0.2140)$. No significant changes in the serum levels of leptin and ApN with positive nodal-status were observed. These results suggest an association of high serum A-FABP levels and nodal involvement in premenopausal cases.

\section{Discussion}

The results of this study demonstrate that A-FABP is associated with breast cancer risk. Further, breast cancer patients with high serum levels of A-FABP have a worse prognosis. We also show significant higher mean serum A-FABP levels in obese over non-obese breast cancer patients and controls, independent of menopausal status.

Adipocytokines, BMI, and the risk of breast cancer

In our cohort, the BMI of breast cancer patients were higher than in women with benign lesions. This is in line with a great majority of data, particularly for postmenopausal women [17-19] demonstrating the link between obesity and breast cancer risk [20-22]. Adipocytokines may partly be responsible for such a relationship. Just recently, however, Rosenberg et al. [23] reported that obese

Table 6 Serum levels of adipocytokines stratified by menopausal status and tumor characteristics

\begin{tabular}{|c|c|c|c|c|c|c|c|c|c|}
\hline & \multicolumn{3}{|c|}{ A-FABP (ng/ml) } & \multicolumn{3}{|c|}{ Leptin (ng/ml) } & \multicolumn{3}{|l|}{$\mathrm{ApN}(\mu \mathrm{g} / \mathrm{ml})$} \\
\hline & All & Prem. $^{\mathrm{b}}$ & Postm. $^{\mathrm{b}}$ & All & Prem. $^{\mathrm{b}}$ & Postm. ${ }^{b}$ & All & Prem. $^{\mathrm{b}}$ & Postm. $^{\mathrm{b}}$ \\
\hline Benign mean \pm SEM & $24.47(2.1)$ & $20.65(2.1)$ & $30.44(4.1)$ & $14.92(2.1)$ & $14.83(2.9)$ & $15.06(2.5)$ & $17.7(1.0)$ & $17.13(1.2)$ & $18.76(1.7)$ \\
\hline $\mathrm{T} 1$ mean $\pm \mathrm{SEM}$ & $32.70(1.6)$ & $22.12(1.8)$ & $36.28(1.9)$ & $19.18(1.6)$ & $11.05(1.4)$ & $21.92(1.9)$ & $18.45(0.7)$ & $16.47(1.1)$ & $19.12(0.9)$ \\
\hline$P$ & $<0.05$ & 0.1535 & 0.1076 & 0.0897 & $<0.05$ & 0.4437 & 0.5076 & 0.2062 & 0.8749 \\
\hline$\geq \mathrm{T} 2$ mean $\pm \mathrm{SEM}$ & $36.29(1.9)$ & $26.18(2.7)$ & $39.47(2.1)$ & $23.08(1.9)$ & $18.17(3.3)$ & $24.62(2.3)$ & $18.80(1.1)$ & $15.27(1.7)$ & $19.91(1.4)$ \\
\hline $\mathrm{G} 1$ mean $\pm \mathrm{SEM}$ & $31.37(5.8)$ & $21.05(4.1)^{\mathrm{a}}$ & 33.67 (11.9) & $20.95(4.6)$ & $11.78(3.4)^{\mathrm{a}}$ & $22.98(9.2)$ & $18.10(2.1)$ & $12.88(4.1)^{\mathrm{a}}$ & $19.26(3.8)$ \\
\hline$P$ & 0.2754 & & 0.1434 & 0.5441 & & 0.5788 & 0.8776 & & 0.8508 \\
\hline$\geq \mathrm{G} 2$ mean $\pm \mathrm{SEM}$ & $34.11(1.2)$ & $24.76(1.6)$ & $37.69(1.3)$ & $19.87(1.2)$ & $15.78(1.9)$ & $21.99(1.5)$ & $18.44(0.6)$ & $15.85(0.9)$ & $19.24(0.8)$ \\
\hline N0 mean \pm SEM & $32.76(1.5)$ & $21.22(1.4)$ & $36.87(1.8)$ & $20.83(1.5)$ & $13.00(1.9)$ & $23.97(1.9)$ & $18.31(0.7)$ & 16.49 & $18.95(0.9)$ \\
\hline$P$ & $<0.05$ & $<0.01$ & 0.2140 & 0.4396 & 0.1408 & 0.0817 & 0.7958 & 0.1259 & 0.2587 \\
\hline $\mathrm{N} 1$ mean $\pm \mathrm{SEM}$ & $36.30(1.7)$ & $30.88(2.9)$ & $38.21(1.9)$ & $18.14(1.8)$ & $19.93(3.6)$ & $17.51(2.1)$ & $18.61(1.2)$ & $14.30(1.8)$ & $20.12(1.5)$ \\
\hline
\end{tabular}

${ }^{a}$ G1 $(n=2)$, Mann-Whitney- $U$-test requires at least three values in each group

b prem. premenopausal, postm. postmenopausal 
Fig. 1 Serum levels of A-FABP and leptin of all breast cancer patients related to tumor characteristics

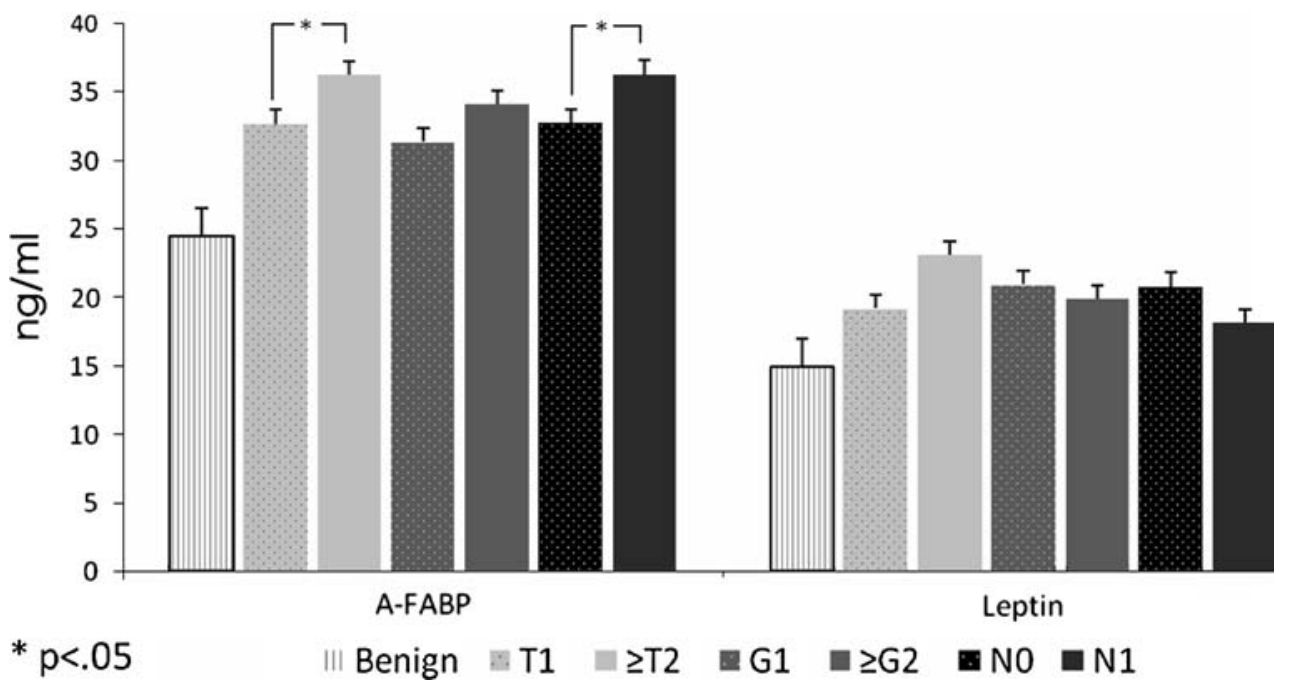

In keeping with the earlier data showing a positive correlation between serum A-FABP levels and BMI [13, 25-29] the mean serum levels of A-FABP in our cohort are significantly higher in obese women than in normal weight women, independent of menopausal status. The range of serum A-FABP levels in our study, between 14.15 and $59.1 \mathrm{ng} / \mathrm{ml}$, is comparable to those reported by Yeung et al. [28], Stejskal et al. [27], and Möhlig et al. [13] (17.0 to $41.9 \mu \mathrm{g} / \mathrm{L}, 23.7$ to $42.4 \mu \mathrm{g} / \mathrm{L}$, and 5.1 to $113.0 \mathrm{ng} / \mathrm{ml}$, respectively).

We, therefore, propose that high A-FABP serum levels are associated with obesity and breast cancer risk and its prognosis.

Our findings of the strong positive association of leptin levels and BMI confirm published data [2, 3, 8]. However, data linking leptin with breast cancer risk are controversial. Petridou et al. [30] reported an inverse relationship of leptin with breast cancer in premenopausal women, but showed no such relationship in postmenopausal women, which is in concert with other studies observing no relationship between serum leptin levels and breast cancer [11, 12, 31-34]. However, contrary to these data, several studies, such as by Tessitore et al. [35, 37], suggest a positive relationship between leptin and breast cancer [36-38]. These inconsistent results could partly be due to the small sample size of patients (Han $n=90$ [38], Chen $n=100$ [36], Ozet $n=30$ [31]), different study designs, or sample preparation. Tessitore et al. [37], for example, included only 23 breast cancer patients, but 103 controls and did not correlate the data with BMI. Two studies observing a positive relationship between leptin and breast cancer did not identify the menopausal status and included both pre- and postmenopausal patients in their analyses [36, 38]. Menopausal status could be a confounding factor, as Cento et al. [39] and Hayase et al. [40] noted higher leptin levels in 
premenopausal than postmenopausal women. In addition, in premenopausal women the state of menstrual cycle should be considered while collecting blood samples, because published data propose that the luteal phase shows higher leptin levels [41-43]. This could possibly pose a limitation in our study, but as the sample collection was conducted randomly to menstrual cycle, we, therefore, suggest that the day of the menstrual cycle is averaged within the subgroups. Most studies analyzed blood serum in the samples, but two studies [37, 44] used plasma samples. Although the practical significance of using blood samples is unclear, Gröschl et al. [45] reported that the leptin concentrations measured exhibit a greater variation range and are lower than in plasmas when using the same blood samples. These confounding factors discussed above show the inhomogeneity of study design and could explain the diversity of results. However, our results confirm these studies suggesting a relationship between elevated leptin levels and breast cancer [35-38], but due to the wide range of findings and inconsistencies of the results, further studies, including a larger sample of women, and accounting for several confounders are warranted.

However, contrary to leptin, serum adiponectin levels decrease with increasing BMI [46]. Our data are in agreement with these published data, and mean serum adiponectin levels are observed to be lower in obese women than in non-obese. Earlier published data $[8,11$, 12] demonstrate an inverse relationship between adiponectin levels and breast cancer risk in pre- and postmenopausal patients. Our data reveal lower adiponectin serum levels in premenopausal, but not in postmenopausal breast cancer patients. In order to reappraise our results, evaluation of the leptin-to-adiponectin-ratio (L/Aratio), just recently introduced, is reasonable. The L/Aratio is expected to play an important role in evaluating breast cancer risk [36, 47]. Clearly et al. even state that this ratio may be more significant in breast cancer than absolute concentrations of these adipocytokines [47]. Chen et al. [36] showed that the L/A-ratio significantly increases in breast cancer patients when compared with controls. In our study, the L/A-ratio also showed significant increase in breast cancer patients compared with controls: L/A ratio $=1.33$ and 1.02 in breast cancer patients and controls, respectively. Therefore, we too submit that the L/A ratio is suitable to determine breast cancer risk.

\section{Adipocytokines and TNM}

Apart from the general increased breast cancer risk in obese women, obese breast cancer patients appear to have a worse prognosis relating to lymph node metastasis, tumor size, and death when compared with non-obese breast cancer patients [3, 48, 49]. Concerning A-FABP and tumor characteristics of breast cancer, to date, no data are available. In our study, higher serum A-FABP levels with greater tumor size and lymph node involvement were found, but not with grading. Therefore, we postulate that A-FABP is associated with poorer prognosis of breast cancer.

There are a few studies on the relationship of serum leptin levels and breast cancer prognosis. Hou et al. [22] as well as Chen et al. [36] found a close relationship between leptin and tumor size, but no correlation to grading or lymph node involvement. Our study also shows raised serum leptin levels with advanced tumor size $(\geq 2 \mathrm{~cm})$ in the total cohort, but with statistical significance only in premenopausal women. No relationship between leptin and grading or lymph node involvement however, was noted. Goodwin et al. [50] observed a significant positive link between elevated concentrations of plasma leptin levels and advanced tumor size, higher tumor grade, and hormone receptor negativity $(n=471)$ in the total cohort, and with highest impact in postmenopausal women; however, after multivariate analyses, no significant decrease in disease-freesurvival (DFS) or overall-survival (OS) was seen. Goodwin et al. postulated that despite including 471 patients, the size of the study could still have limited the identification of prognostic effects (study population of the other studies was $n=80$ [22], $n=100$ [36], and $n=135$ in our study). Therefore, while an adverse prognostic effect of leptin could be possible, to date there is too little evidence to postulate that leptin alters prognosis.

Several data suggest an inverse correlation of serum levels of ApN and clinicopathological characteristics of tumors [11, 22, 36]. Miyoshi et al. [11] included 102 breast cancer patients and showed a higher frequency of large tumors $(>2 \mathrm{~cm})$ and high histological grade $(\mathrm{G} 2, \mathrm{G} 3)$ in women with decreased serum adiponectin levels, but no relationship with lymph node involvement or hormone receptor status was noted. On the contrary, results of Chen et al. [36] or Hou et al. [22] did not show any relationship between serum adiponectin levels and tumor size. Our study showed no relationship between ApN and tumor characteristics, confirming this. The disparity of published data to date could be due to the meager number of studies (four including ours) considering this problem, and again to the rather small number of breast cancer patients included: $n=102$ (Miyoshi et al. [11]), $n=100$ (Chen et al. [36]), $n=80$ (Hou et al. [22]), and $n=135$ (our study). Therefore, we are unable to definitely postulate a relationship between $\mathrm{ApN}$ and prognostic factors of breast cancer. 


\section{Conclusion}

In our study, we identified A-FABP as a novel prognostic factor in breast cancer patients, which is associated with the risk of breast cancer and confirmed the association of A-FABP and obesity. Further, the connection between A-FABP and tumor size and lymph node involvement propose a poorer prognosis of breast cancer with elevated A-FABP levels. However, further studies are warranted to confirm our data and to acquire additional information on the prognostic value of A-FABP and breast cancer risk.

Acknowledgments Statistical analyses were reviewed by Mrs. Hay and Mrs. Gerstner, official staff of the biometric institute of the University of Ulm.

\section{References}

1. Pignatelli M, Cocca C, Santos A, Perez-Castillo A (2003) Enhancement of BRCA1 gene expression by the peroxisome proliferator-activated receptor gamma in the MCF-7 breast cancer cell line. Oncogene 22:5446-5450

2. Housa D, Housova J, Vernerova Z, Haluzik M (2006) Adipocytokines and cancer. Physiol Res 55:233-244

3. Lorincz A, Sukumar S (2006) Molecular links between obesity and breast cancer. Endocr Relat Cancer 13:279-292

4. Lahmann PH, Hoffmann K, Allen N et al (2004) Body size and breast cancer risk: findings from the European Prospective Investigation into Cancer And Nutrition (EPIC). Int J Cancer 111:762-771

5. van den Brandt PA, Spiegelman D, Yaun SS et al (2000) Pooled analysis of prospective cohort studies on height, weight, and breast cancer risk. Am J Epidemiol 152:514-527

6. Rose D, Komninou D, Stephenson G (2004) Obesity, adipocytokines, and insulin resistance in breast cancer. Obes Rev 5:153165

7. Fletcher O, Gibson L, Johnson N, Altmann DR, Holly JMP, Ashworth A, Peto J, Silva IDS (2005) Polymorphisms and circulating levels in the insulin-like growth factor system and risk of breast cancer: a systematic review. Cancer Epidemiol Biomarkers Prev 14:2-19

8. Vona-Davis L, Rose DP (2007) Adipokines as endocrine, paracrine, and autocrine factors in breast cancer risk and progression. Endocr Rel Cancer 14:189-206

9. Rohner-Jeanrenaud F, Jeanrenaud B (1996) The discovery of leptin and its impact in the understanding of obesity. Eur $\mathbf{J}$ Endocrinol/European Federation of Endocrine Societies 135:649-650

10. Ishikawa M, Kitayama J, Nagawa H (2004) Enhanced expression of leptin and leptin receptor (OB-R) in human breast cancer. Clin Cancer Res 10:4325-4331

11. Miyoshi Y, Funahashi T, Kihara S, Taguchi T, Tamaki Y, Matsuzawa Y, Noguchi S (2003) Association of serum adiponectin levels with breast cancer risk. Clin Cancer Res 9:5699-5704

12. Mantzoros C, Petridou E, Dessypris N, Chavelas C, Dalamaga M, Alexe DM, Papadiamantis Y, Markopoulos C, Spanos E, Chrousos G, Trichopoulos D (2004) Adiponectin and breast cancer risk. J Clin Endocrinol Metab 89:1102-1107

13. Möhlig M, Weickert MO, Ghadamgadai E, Machlitt A, Pfüller B, Arafat AM, Pfeiffer AFH, Schöfl C (2007) Adipocyte fatty acidbinding protein is associated with markers of obesity, but is an unlikely link between obesity, insulin resistance, and hyperandrogenism in polycystic ovary syndrome women. Eur J Endocrinol/European Federation of Endocrine Societies 157:195-200

14. Boord JB, Fazio S, Linton MF (2002) Cytoplasmic fatty acidbinding proteins: emerging roles in metabolism and atherosclerosis. Curr Opin Lipidol 13:141-147

15. Hammamieh R, Chakraborty N, Barmada M, Das R, Jett M (2005) Expression patterns of fatty acid binding proteins in breast cancer cells. J Exp Therap Oncol 5:133-143

16. Li H, Lu Q, Dong L, Xue H, Zhou H, Yang H (2007) Expression of fatty acid binding protein in human breast cancer tissues. Chin J Cell Mol Immunol 23:312-316. (in Chinese by Xi Bao Yu Fen Zi Mian Yi Xue Za Zhi)

17. Swanson CA, Coates RJ, Schoenberg JB, Malone KE, Gammon MD, Stanford JL, Shorr IJ, Potischman NA, Brinton LA (1996) Body size and breast cancer risk among women under age 45 years. Am J Epidemiol 143:698-706

18. Franceschi S, Favero A, La Vecchia C, Barón AE, Negri E, Dal Maso L, Giacosa A, Montella M, Conti E, Amadori D (1996) Body size indices and breast cancer risk before and after menopause. Int J Cancer 67:181-186

19. van den Brandt PA, Dirx MJ, Ronckers CM, van den Hoogen P, Goldbohm RA (1997) Height, weight change, and postmenopausal breast cancer risk: the Netherlands Cohort Study. Cancer Causes Control 8:39-47

20. Montazeri A, Sadighi J, Farzadi F, Maftoon F, Vahdaninia M, Ansari M, Sajadian A, Ebrahimi M, Haghighat S, Harirchi I (2008) Weight, height, body mass index and risk of breast cancer in postmenopausal women: a case-control study. BMC Cancer 8:278

21. Trentham-Dietz A, Newcomb PA, Egan KM, Titus-Ernstoff L, Baron JA, Storer BE, Stampfer M, Willett WC (2000) Weight change and risk of postmenopausal breast cancer (United States). Cancer Causes Control 11:533-542

22. Hou W, Xu Y, Yu T, Zhang L, Zhang W, Fu C, Sun Y, Wu Q, Chen L (2007) Adipocytokines and breast cancer risk. Chin Med J 120:1592-1596

23. Rosenberg L, Czene K, Hall P (2009) Obesity and poor breast cancer prognosis: an illusion because of hormone replacement therapy. Br J Cancer 100(9):1486-1491

24. Das R, Hammamieh R, Neill R, Melhem M, Jett M (2001) Expression pattern of fatty acid-binding proteins in human normal and cancer prostate cells and tissues. Clin Cancer Res $7: 1706-1715$

25. Ohlsson G, Moreira JMA, Gromov P, Sauter G, Celis JE (2005) Loss of expression of the adipocyte-type fatty acid-binding protein (A-FABP) is associated with progression of human urothelial carcinomas. Mol Cell Proteomics 4:570-581

26. Xu A, Wang Y, Xu JY, Stejskal D, Tam S, Zhang J, Wat NMS, Wong WK, Lam KSL (2006) Adipocyte fatty acid-binding protein is a plasma biomarker closely associated with obesity and metabolic syndrome. Clin Chem 52:405-413

27. Stejskal D, Karpisek M (2006) Adipocyte fatty acid binding protein in a Caucasian population: a new marker of metabolic syndrome? Eur J Clin Investig 36:621-625

28. Yeung DCY, Xu A, Cheung CWS, Wat NMS, Yau MH, Fong CHY, Chau MT, Lam KSL (2007) Serum adipocyte fatty acidbinding protein levels were independently associated with carotid atherosclerosis. Arterioscler Thromb Vasc Biol 27:1796-1802

29. Koh JH, Shin YG, Nam SM, Lee MY, Chung CH, Shin JY (2009) Serum adipocyte fatty acid-binding protein levels are associated with nonalcoholic fatty liver disease in type 2 diabetic patients. Diabetes Care 32:147-152

30. Petridou E, Papadiamantis Y, Markopoulos C, Spanos E, Dessypris N, Trichopoulos D (2000) Leptin and insulin growth factor I in relation to breast cancer (Greece). Cancer Causes Control 11:383-388 
31. Ozet A, Arpaci F, Yilmaz MI, Ayta H, Ozturk B, Komurcu S, Yavuz AA, Tezcan Y, Acikel C (2001) Effects of tamoxifen on the serum leptin level in patients with breast cancer. Jpn J Clin Oncol 31:424-427

32. Coskun U, Günel N, Toruner FB, Sancak B, Onuk E, Bayram O, Cengiz O, Yilmaz E, Elbeg S, Ozkan S (2003) Serum leptin, prolactin and vascular endothelial growth factor (VEGF) levels in patients with breast cancer. Neoplasma 50:41-46

33. Sauter ER, Garofalo C, Hewett J, Hewett JE, Morelli C, Surmacz E (2004) Leptin expression in breast nipple aspirate fluid (NAF) and serum is influenced by body mass index (BMI) but not by the presence of breast cancer. Horm Metab Res 36:336-340

34. Woo H, Park H, Ki C, Park YL, Bae WG (2006) Relationships among serum leptin, leptin receptor gene polymorphisms, and breast cancer in Korea. Cancer Lett 237:137-142

35. Tessitore L, Vizio B, Pesola D, Cecchini F, Mussa A, Argiles JM, Benedetto C (2004) Adipocyte expression and circulating levels of leptin increase in both gynaecological and breast cancer patients. Int J Oncol 24:1529-1535

36. Chen D, Chung Y, Yeh Y, Chaung H, Kuo F, Fu O, Chen H, Hou M, Yuan SF (2006) Serum adiponectin and leptin levels in Taiwanese breast cancer patients. Cancer Lett 237:109-114

37. Tessitore L, Vizio B, Jenkins O, De Stefano I, Ritossa C, Argiles JM, Benedetto C, Mussa A (2000) Leptin expression in colorectal and breast cancer patients. Int J Mol Med 5:421-426

38. Han C, Zhang H, Du L, Liu X, Jing J, Zhao X, Yang X, Tian B (2005) Serum levels of leptin, insulin, and lipids in relation to breast cancer in china. Endocrine 26:19-24

39. Cento RM, Proto C, Spada RS, Napolitano V, Ciampelli M, Cucinelli F, Lanzone A (1999) Leptin levels in menopause: effect of estrogen replacement therapy. Horm Res 52:269-273

40. Hayase H, Nomura S, Abe T, Izawa T (2002) Relation between fat distributions and several plasma adipocytokines after exercise training in premenopausal and postmenopausal women. J Physiol Anthropol Appl Hum Sci 21:105-113

41. Riad-Gabriel MG, Jinagouda SD, Sharma A, Boyadjian R, Saad MF (1998) Changes in plasma leptin during the menstrual cycle.
Eur J Endocrinol/European Federation of Endocrine Societies 139:528-531

42. Cella F, Giordano G, Cordera R (2000) Serum leptin concentrations during the menstrual cycle in normal-weight women: effects of an oral triphasic estrogen-progestin medication. Eur J Endocrinol/European Federation of Endocrine Societies 142:174-178

43. Geisthövel F, Jochmann N, Widjaja A, Horn R, Brabant G (2004) Serum pattern of circulating free leptin, bound leptin, and soluble leptin receptor in the physiological menstrual cycle. Fertil Steril 81:398-402

44. Stattin P, Söderberg S, Biessy C, Lenner P, Hallmans G, Kaaks R, Olsson $T$ (2004) Plasma leptin and breast cancer risk: a prospective study in northern Sweden. Breast Cancer Res Treat 86:191-196

45. Gröschl M, Wagner R, Dörr HG, Blum W, Rascher W, Dötsch J (2000) Variability of leptin values measured from different sample matrices. Horm Res 54:26-31

46. Steffes MW, Gross MD, Schreiner PJ, Yu X, Hilner JE, Gingerich R, Jacobs DR (2004) Serum adiponectin in young adultsinteractions with central adiposity, circulating levels of glucose, and insulin resistance: the CARDIA study. Ann Epidemiol 14:492-498

47. Cleary MP, Ray A, Rogozina OP, Dogan S, Grossmann ME (2009) Targeting the adiponectin: leptin ratio for postmenopausal breast cancer prevention. Front Biosci (schol Ed) 1:329-357

48. Berclaz G, Li S, Price KN, Coates AS, Castiglione-Gertsch M, Rudenstam C, Holmberg SB, Lindtner J, Erien D, Collins J, Snyder R, Thürlimann B, Fey MF, Mendiola C, Werner ID, Simoncini E, Crivellari D, Gelber RD, Goldhirsch A (2004) Body mass index as a prognostic feature in operable breast cancer: the International Breast Cancer Study Group experience. Ann Oncol 15:875-884

49. Calle EE, Rodriguez C, Walker-Thurmond K, Thun MJ (2003) Overweight, obesity, and mortality from cancer in a prospectively studied cohort of U.S. adults. New Engl J Med 348:1625-1638

50. Goodwin PJ, Ennis M, Fantus IG, Pritchard KI, Trudeau ME, Koo J, Hood N (2005) Is leptin a mediator of adverse prognostic effects of obesity in breast cancer? J Clin Oncol 23:6037-6042 